\title{
The Effectiveness of STEAM-Based Augmented Reality Media in Improving the Quality of Natural Science Learning in Elementary School
}

\author{
Idam Ragil Widianto Atmojo', Roy Ardiansyah 2, Dwi Yuniasih Saputri 3, \\ Fadhil Purnama Adi4
}

DOI: 10.35445/alishlah.v13i2. 643

\section{Article Info}

Keywords: Augmented reality; Science learning; STEAM

Kata kunci: Augmented reality; Pembelajaran IPA; STEAM

\section{Abstract}

This study describes the effectiveness of STEAM-based augmented reality (AR) learning media in natural science learning in elementary schools. This research used an experimental method. Six schools were involved as the subjects of this research, which was consisted of 3 elementary schools for experimental classes (6o students) and three elementary schools for control classes (6o students). The teachers involved were the 6th grader teachers. The data collection technique used 30 multiple choices questions for the students. The study results concluded that STEAM-based augmented reality effectively improved the quality of natural science learning in elementary schools. The t-test calculation results utilizing SPSS obtained t-count of $2.874>\mathrm{t}$-table of $1.98 \mathrm{o}(\mathrm{df}-2=122-2=$ 120). The normalized gain results showed a significant increase before and after using STEAM-based augmented reality media in natural science learning in elementary schools, which was 0.72 included in the high category. This research implies that research helps teachers optimize the use of media and teaching approaches. One of them is the use of STEAM with augmented reality media.

\begin{abstract}
Abstrak
Tujuan penelitian ini adalah mendeskripsikan keefektifan media pembelajaran augmented reality (AR) berbasis STEAM dalam pembelajaran IPA di sekolah dasar. Penelitian ini menggunakan metode eksperimen. Subjek penelitian yang dilibatkan yaitu 6 sekolah dasar yang terdiri dari 3 sekolah dasar untuk kelas eksperimen (6o siswa) dan 3 sekolah dasar untuk kelas control (62 siswa). Jumlah guru yang terlibat yaitu 6 guru ke las. Teknik pengumpulan data menggunakan tes soal pilihan ganda berjumlah 30 soal untuk siswa. Hasil penelitian dapat disimpulkan bahwa augmented reality berbasis STEAM efektif untuk meningkatkan kualitas pembelajaran IPA di SD. Hasil perhitungan uji-t menggunakan SPSS didapatkan t-tabel sebesar $2,874>$ dari $t$ table $1,980(\mathrm{df}-2=122-2=120)$. Hasil normalized gain menunjukkan adanya peningkatan yang signifikan sebelum dan sesudah menggunakan media augmented reality berbasis STEAM pada pembelajaran IPA di SD yaitu 0,72 yang termasuk dalam kategori tinggi. Penelitian ini memberikan implikasi bahwa hasil penelitian dapat menjadi masukan kepada
\end{abstract}

\footnotetext{
${ }^{1}$ Universitas Sebelas Maret, Indonesia

Email: idamragil@fkip.uns.ac.id 2 Universitas Sebelas Maret, Indonesia Email: royardiansyah@staff.uns.ac.id 3 Universitas Sebelas Maret, Indonesia Email: dwiyuniasihsaputri@staff.uns.ac.id

4 Universitas Sebelas Maret, Indonesia

Email: fadhil@staff.uns.ac.id
} 
guru untuk mengoptimalkan media dan pendekatan pembelajaran, salah satunya penggunaaan pendekatan STEAM dengan media augmented reality.

\section{INTRODUCTION}

Students often found obstacles in understanding abstract concepts in each natural science material (Palmer, 1999). In this case, natural science learning supported by technology is more effective than natural science learning conventional classes. Technological support encourages students to learn factual knowledge in natural science courses (Rehmat \& Bailey, 2014). The use of virtual technology makes it easier for students to improve understanding because it can present abstract concepts (Arvanitis et al., 2009). More specifically, Augmented Reality (AR) technology can visualize three dimensions, facilitate reality, and provide students with an understanding of complex material (P. H. Wu et al., 2018).

Multimedia programs and multimedia learning environments can increase the type of information students have access to and active participation (Lloret, M., Aguilar, E., \& Lloret, 2009). The increased availability, sophistication, and use of these tools can make it easier for teachers to accomplish efficient and effective learning under the learning objectives. Utilizing multimedia in learning allows students to increase learning activities, learning outcomes, and skills required in the 21st century (Morris \& Lambe, 2017). In addition, interactive multimedia presents material by combining several modes to make the media more effective, efficient, and interesting for students. Learning by using multimedia is more fun and can help students achieve optimal learning outcomes. Based on the research results, interactive multimedia in learning natural sciences could facilitate problem-solving ability (Rajendra \& Sudana, 2018).

Moreover, technological developments have led to new technologies in learning, namely reality, as a tool for teacher's teaching and innovative researchers in Universities (Tekedere \& Göker, 2016). The convenience provided in augmented reality is able to visualize a combination of natural and virtual environments interestingly. It makes the display more interactive in real-time and integrated with the three-dimensional display (Azuma, 1997; Ozdemir et al., 2018; Tekedere \& Göker, 2016). The seamless integration of digital information with the real-world environment makes the boundary between the two very thin. One experience provided by augmented reality is the interaction of virtual objects directly for the user, providing the most natural and authentic humancomputer interaction experience (S Cai et al., 2014). Thus, AR can be an attractive technology choice for interactive multimedia in natural science learning by elementary school teachers, ensuring learning by doing and learning based on experience. Thus, AR can be an attractive technology choice for interactive multimedia in natural science learning by elementary school teachers under natural science learning characteristics that provide opportunities for experimentation. The use of AR technology in the learning process also facilitates students to construct knowledge independently. Students can organize their learning process according to their wishes and manipulate objects that are not in the environment but appear to be real around them by being enlarged to gain understanding and knowledge (Wang, 2012). Augmented reality can also be a solution for learning in areas with inadequate signals (Risdianto \& Fathurrochman, 2021).

Students can quickly learn specific concepts through the $3 \mathrm{D}$ interaction facilities in AR-based interactive multimedia (Martín-Gutiérrez et al., 2010). Besides, in the use of AR-based interactive multimedia, especially in science learning, the technology offered provides opportunities for students to interact with the physical world virtually without any direct physical contact (Grubert et al., 2011). On mobile devices, the application of AR technology creates new types of services and applications that can improve the quality of science learning (Joan, 2015). AR-based multimedia is also a way to make learning by elementary school teachers more exciting and fun. Moreover, AR provides an opportunity to explore the way of teaching more deeply, especially in learning natural sciences in elementary school. 
However, in reality, many teachers have not implemented a teaching approach in science learning. The learning is still teacher-centred, where the students do not actively participate in the teaching-learning process. The methods used are lecturer, question and answer, and assignment. The teachers also often use books and pictures as the media. These all bring an impact on the students' common understanding and learning outcomes.

For this reason, the application of AR in elementary schools requires an appropriate learning model in its application, one of which is by applying STEAM-based learning (Science, Technology, Engineering, Art, and Mathematics). The STEAM learning model provides knowledge from various disciplinary points of view, but students are also directed to apply the knowledge and skills they gain (Beswick \& Fraser, 2019). STEAM invites students to integrate subjects and correlate them with everyday life (Caldis, 2019). According to Permanasari (2016), the definition of STEAM is a learning approach that involves several disciplines, covering science, technology, engineering, art, and mathematics, integrated into a lesson. This approach makes students closer to the surrounding environment because it connects learning in authentic contexts, which will later bridge schools to prepare students to thrive in work and apply knowledge in society to develop STEAM. Slovacek et al. (2019) expressed that developed countries such as the United States have used STEAM to overcome problems and challenges that arise in the 21st-century. It certainly does not rule out the possibility for developing countries, such as Indonesia, to use STEAM to compete in various aspects in this modern era. Also, the STEAM learning process involves several critical skills for 21st-century learners: collaboration, creativity, critical thinking, computerization, cultural understanding, and independent learning and career. Thus, STEAM is designed to prepare students to face global competition by connecting the four aspects: science, technology, engineering, and mathematics. The four aspects of STEAM can make knowledge more meaningful if integrated with the learning process. It is expected to produce meaningful learning for students by integrating knowledge, concepts, and logical skills (Arifin et al., 2020).

The previous research conducted by Jession et al. (2020) shows that using STEAM with augmented reality effectively improves student' activeness. The students find out that learning with AR technology is fun and improves their learning experience. This research shows that this kind of learning can develop students' ability by case study, managing the team, and interacting with the other students to make the teaching-learning holistic and fun.

Based on the problems above, the researchers analyzed STEAM-based AR's effectiveness. The findings of this study are expected to provide STEAM-based AR specifications suitable for elementary schools. This research is crucial to be conducted in elementary schools because of nowaday's low quality of learning. The learning quality can be improved using an approach and innovative teaching media. The STEAM approach is suitable with the elementary students' holistic characteristics to understand the problem from many points of view, i.e., various indiscipline. The use of AR can facilitate the students with operational concrete thinking to visualize the abstract concepts.

\section{METHODS}

This study used experimental research methods to analyze the effectiveness of STEAM-based AR to improve the quality of natural science learning in elementary schools. Six schools were involved as the subjects of this research, which was consisted of 3 elementary schools for experimental classes (6o students) and three elementary schools for control classes (62 students). The teachers involved were the 6 th grader teachers. The data collection technique used 30 multiple choices questions for the students. The increased learning quality was seen from the comparison test of two paired samples, while to see an increase in learning quality, it was seen from the normalized gain. The data were then analyzed using the Independent Sample T-test. The acceptance or rejection of Ho used the significant value in the Paired Sample T-test table in column t (calculation with SPSS). 
If the significance value is $>5 \%$, Ho is accepted. The following normalized gain ( $\mathrm{g}$ ) formula was used to see how much increase occurred:

$$
<g>=\frac{\text { posttest scores }- \text { pretest scores }}{\text { maximum value }- \text { pretest score }}
$$

Furthermore, the value of normalized gain (g) obtained was translated according to the criteria for obtaining normalized gain (g), as presented in Table 1 below.

\begin{tabular}{cc} 
Table 1. Criteria for the Obtained Normalized Gain $\langle\mathbf{g}\rangle$ \\
\hline Normalized Gain $<\mathrm{g}>$ & Criteria \\
\hline$<\mathrm{g}><0,3$ & Low \\
\hline $0,3 \leq<\mathrm{g}>0,7$ & Moderate \\
\hline$<\mathrm{g}>>0,7$ & High \\
\hline
\end{tabular}

\section{FINDINGS AND DISCUSSION}

Based on the t-test results, STEAM-based augmented reality media effectively improved the quality of natural science learning, seen from the learning outcomes before and after utilizing STEAM-based augmented reality media. The t-test was carried out with the prerequisite test stages, namely the normality test to know whether the data were normally distributed or not and the homogeneity test to determine whether the population's variance was homogeneous. The normality test results calculated utilizing SPSS revealed that the data were normally distributed, with 0.63. Meanwhile, the homogeneity test results of both experimental and control samples were 0.57, so it was stated that the two samples had homogeneous variants. Furthermore, the t-test calculation results utilizing SPSS obtained a t-count of $2.874>\mathrm{t}$-table of $1.980(\mathrm{df}-2=122-2=120)$. The $\mathrm{t}$-count was higher than the t-table, Ho was rejected, and Ha was accepted. There was a significant difference between students who used STEAM-based augmented reality in learning natural sciences (60 students) compared to those who did not use STEAM-based augmented reality (62 students). The normalized gain results also uncovered a significant increase before and after using STEAM-based augmented reality media, 0.72 in the high category.

In this case, STEAM-based augmented reality is effective in improving the quality of learning. According to the study results, augmented reality can simultaneously combine virtual and real objects to create quality learning (Saputra et al., 2020). The use of augmented reality can also encourage social and cognitive activities, motivation, and critical thinking, emphasizing physical movement so that students can be active in learning and teachers can explore new strategies to gain learning experiences (Curcio et al., 2016; Herpich et al., 2017; Peterson \& Stone Andrew, 2019). In addition, previous studies' results have proven that augmented reality effectively helped students achieve conceptual understanding, both abstractly and even complex concepts (Fernandez, 2017).

Moreover, education in the current era accelerates teachers and students in integrating technology to attain 21st-century skills, which is constantly developing quickly. Indonesia has responded to this condition by including STEAM education in the 2013 curriculum revision (Ishartono et al., 2021). The STEAM approach is applied in learning utilizing augmented reality by designing a theme, which covers inter-and transdisciplinary. The activity begins with giving a case/problem that allows students to realize a project and find concepts, knowledge, and materials. Students then apply knowledge in real life (Herpich et al., 2019). According to Taylor (in Badmus Taofeek \& Omosewo Esther, 2018), STEAM also allows students to learn from various perspectives of interrelated knowledge, such as self-understanding of the culture close to the environment students live in, social relationships or interactions, critical thinking development, forward-looking or visionary and ethical knowledge, and meaningful experiences to students. STEAM can also improve intrapersonal skills, reformulating beliefs, attitudes, and competencies to understand the complex world in the scientific realm and the social realm (Bassachs et al., 2020). 
Further, STEAM is an alternative application of several disciplines combined into learning designs, which provide opportunities for students to develop scientific thinking, be creative, and conduct experiments in a meaningful way to increase their interest (Conner et al., 2017). Students also gain experience to develop the ability to observe through the technology created. In addition, students create technology, apply it, and express themselves through art (Prezhdarova \& Pastarmadzhieva, 2020).

According to respondents, the users of interactive media need to be used in their learning process. It aligns with the study results (Astuti, 2015), which stated that ICT media is very suitable for the learning process to increase student motivation. This interactive multimedia obtained by making it independently was based on four respondents' opinions. In addition, another more straightforward way by searching on the internet was conveyed by four respondents who chose the answer. Regarding this, learning media is an essential part of learning in the classroom. Thus, choosing suitable learning media will make learning more exciting and meaningful (Gunawan et al., 2017).

In contrast, the selection of inappropriate learning media can also cause learning to be monotonous. The choice of learning media can also affect the level of difficulty of the content presented to students. Learning media can make complex material easy for students to understand; on the other hand, learning media can make simple material difficult for students to understand. The excellent and impaired quality of learning can be seen from one factor influencing it: learning media. The selection of suitable learning media can affect the success of the learning carried out in achieving the learning objectives. For this reason, AR (augmented reality) is a solution to contribute to learning objectives.

$\mathrm{AR}$ is an application that provides learning to see from two sides: the merger between the digital world and the physical world, which scans barcodes. Thus, children will prefer to play using augmented reality because the objects displayed are three-dimensional. AR in learning provides many advantages for achieving learning success because it has interesting content, namely a multimodal display that motivates students to be actively involved in learning. This display makes it easy for students to see abstract material concepts in real terms. The content in augmented reality can be in the form of text, images, videos, and $3 \mathrm{D}$ objects to stimulate listening skills, get new vocabulary, and other language skills (Glockner, Jannek, Mahn, 2014).

In addition, $A R$ is a technology that can insert information into the virtual world and display it to the real world with the help of computer webcams, cameras, and even special glasses. This study reinforces the previous studies' results that the use of AR could reduce verbalism, which impacted students' misunderstandings or multiple interpretations of the material being taught so that it could help students improve understanding of the material (Radu, 2014; Yen et al., 2013), improve student creativity (Wei et al., 2015), increase student interest and motivation (Su Cai et al., 2017; Delello, 2014; Martín-Gutiérrez et al., 2010; Nusir et al., 2013; Tomi \& Rambli, 2013), and improve student performance (Fleck \& Simon, 2013; Sin \& Zaman, 2010; Thomas et al., 2019; Vilkoniene, 2009; Wang, n.d.; Zhang et al., 2014). In addition, concepts that cannot be reached when seen with the naked eye can be visualized utilizing augmented reality so that they are suitable to be applied to elementary school students who are still in the concrete operational stage.

Furthermore, the use of augmented reality technology is easy for teachers to operate because they use smartphones. Augmented reality integrated with the STEAM approach (Science, Technology, Engineering Art \& Math) can improve results, and learning activities occur in a playful and fun way (Mufidah, 2019). H. K. Wu et al. (2013) emphasized that augmented reality has potential applications in the STEAM approach. In line with that, Sirakaya (2018) revealed that augmented reality supports learning and the learning process in her research results. Augmented reality can be a medium in applying one of the STEAM components, namely the technology component. STEAM links five fields of science, namely science, technology, engineering, art, and mathematics. Learning 
with the STEAM approach is contextual learning, where children will be invited to understand the phenomena that occur close to themselves (Yakman \& Lee, 2012). Collaboration, cooperation, and communication will appear in the learning process because this approach is carried out in groups. By integrating augmented reality with STEAM, children can use various features found in augmented reality so that there are many opportunities to listen, practise vocabulary, and collaborate with other children. Wittayakhom \& Piriyasurawong (2020) also stated that the STEAM approach is the right approach for elementary school students, whose learning is holistic by combining science, technology, engineering, art, and mathematics. The five disciplines become one of the educational approaches that comprehensively reflect problem-solving through 21st-century learning experiences. STEAM is cooperative learning as part of constructivism learning, where students will build their knowledge and understanding through projects. The given project requires students to understand the material being studied and utilize developing technology to help find concepts.

\section{CONCLUSION}

The study results could be concluded that AR-based interactive multimedia effectively improved the quality of natural science learning. Natural science learning media already involves various media (multimedia), interactive, presenting more real objects, attractive, friendly designs, and equipped with instructions to improve the quality of natural science learning in elementary schools. This research implies that research helps teachers optimize media and teaching approaches; one of them is using STEAM with augmented reality media.

\section{REFERENCES}

Arifin, S., Wahyudin, W., \& Herman, T. (2020). The effects of contextual group guided discovery learning on students' mathematical understanding and reasoning. Jurnal Prima Edukasia. https://doi.org/10.21831/jpe.v8i2.33059

Arvanitis, T. N., Petrou, A., Knight, J. F., Savas, S., Sotiriou, S., Gargalakos, M., \& Gialouri, E. (2009). Human factors and qualitative pedagogical evaluation of a mobile augmented reality system for science education used by learners with physical disabilities. Personal and Ubiquitous Computing. https://doi.org/10.1007/s00779-007-0187-7

Astuti, Y. D. (2015). Dari Simulasi Realitas Sosial Hingga Hiper-Realitas Visual: Tinjauan Komunikasi Virtual Melalui Sosial Media di Cyberspace. Profetik.

Azuma, R. T. (1997). A Survey of Augmented Reality. Presence: Teleoperators and Virtual Environments, $6(4)$, $355-385$. https://doi.org/https://doi.org/https://doi.org/10.1162/pres.1997.6.4.355

Badmus Taofeek, O., \& Omosewo Esther, O. (2018). Evolution of STEM, STEAM and STREAM Education in Africa: The Implication of the Knowledge Gap. International Journal on Research in STEM Education, 2(2), 99-106.

Bassachs, M., Cañabate, D., Serra, T., \& Bubnys, R. (2020). Fostering Critical Reflection in Primary Education through STEAM Approaches. Education Sciences, 10(384), 1-14.

Beswick, K., \& Fraser, S. (2019). Developing mathematics teachers' 21st century competence for teaching in STEM contexts. ZDM - Mathematics Education. https://doi.org/10.1007/s11858019-01084-2

Cai, S, Wang, X., \& Chiang, F. K. (2014). A case study of Augmented Reality simulation system application in a chemistry course. Computers in Human Behavior. https://doi.org/https://doi.org/10.1016/j.chb.2014.04.018

Cai, Su, Chiang, F. K., Sun, Y., Lin, C., \& Lee, J. J. (2017). Applications of augmented reality-based natural interactive learning in magnetic field instruction. Interactive Learning Environments. https://doi.org/10.1080/10494820.2016.1181094

Conner, L. D. C., Tzou, C., Tsurusaki, B. K., Guthrie, M., Pompea, S., \& Teal-Sullivan, P. (2017). Designing STEAM for Broad Participation in Science. Creative Education, 08(14), 22222231. https://doi.org/10.4236/ce.2017.814152

Curcio, I. D. D., Dipace, A., \& Norlund, A. (2016). Virtual realities and education. Research on Education and Media, 8(2), 60-68. https://doi.org/10.1515/rem-2016-0019

Delello, J. A. (2014). Insights from pre-service teachers using science-based augmented reality. Journal of Computers in Education. https://doi.org/10.1007/s40692-014-0021-y 
Fernandez, M. (2017). Augmented Virtual Reality : How to Improve Education Systems. Higher Learning Research Communications, 7(1), 1-15.

Fleck, S., \& Simon, G. (2013). An augmented reality environment for astronomy learning in elementary grades: An exploratory study. IHM 2013 - Actes de La 25ieme Conference Francophone Sur l'Interaction Homme-Machine. https://doi.org/10.1145/2534903.2534907

Glockner, Jannek, Mahn, T. (2014). Augmented reality in Logistics - Chaning the way we see logistics (a DHL perspective). DHL Customer Solutions \& Innovations.

Grubert, J., Langlotz, T., \& Grasset, R. (2011). Augmented Reality Browser Survey. Technical Report. Gunawan, G., Sahidu, H., Harjono, A., \& Suranti, N. (2017). The Effect of Project Based Learning with Virtual Media Assistance on Student's Creativity in Physics. Cakrawala Pendidikan.

Herpich, F., Guarese, R. L. M., \& Tarouco, L. M. R. (2017). A Comparative Analysis of Augmented Reality Frameworks Aimed at the Development of Educational Applications. Creative Education, 08(09), 1433-1451. https://doi.org/10.4236/ce.2017.89101

Herpich, F., Nunes, F. B., Petri, G., \& Tarouco, L. M. R. (2019). How Mobile Augmented Reality Is Applied in Education? A Systematic Literature Review. Creative Education, 10(07), 15891627. https://doi.org/10.4236/ce.2019.107115

Ishartono, N., Sutama, Prayitno, H. J., Irfan, M., Waluyo, M., \& Sufahani, S. F. Bin. (2021). An Investigation of Indonesian In-Service Mathematics Teachers' Perception and Attitude Toward STEAM Education. Journal of Physics: Conference Series, 1776(1). https://doi.org/10.1088/1742-6596/1776/1/012021

Jesionkowska, J., Wild, F., \& Deval, Y. (2020). Active learning augmented reality for STEAM education-A case study. Education Sciences, 10(8), 198.

Joan, R. (2015). Enhancing Education through Mobile Augmented Reality. I-Manager's Journal of Educational Technologi, 11(4), 8-14.

Lloret, M., Aguilar, E., \& Lloret, A. (2009). Self-regulated learning using multimedia programs in dentistry postgraduate students: A multimethod approach. Electronic Journal of Elementary Education, 2(1), 101-121.

Martín-Gutiérrez, J., Luís Saorín, J., Contero, M., Alcañiz, M., Pérez-López, D. C., \& Ortega, M. (2010). Design and validation of an augmented book for spatial abilities development in engineering students. Computers \& Graphics, 34(1), 77-91. https://doi.org/https://doi.org/10.1016/J.CAG.2009.11.003

Morris, N. P., \& Lambe, J. (2017). Multimedia interactive eBooks in laboratory bioscience education. Higher Education $\quad$ Pedagogies, 28-42. https://doi.org/https://doi.org/10.1080/23752696.2017.1338531

Mufidah, I. A. (2019). The Implementation Of Science, Technology, Engineering, And Mathematics (Stem) Learning To Improve Basic Asking Skills And Learning Achievements Students Of Elementary School. AL-ISHLAH: Jurnal Pendidikan. https://doi.org/10.35445/alishlah.v11i2.133

Nusir, S., Alsmadi, I., Al-Kabi, M., \& Sharadgah, F. (2013). Studying the impact of using multimedia interactive programs on children's ability to learn basic math skills. E-Learning and Digital Media, 10(3), 305-319.

Ozdemir, M., Sahin, C., Arxagok, S., \& Demir, M. K. (2018). The Effect of Augmented Reality Applications in the Learning Process: A MetaAnalysis Study. Eurasian Journal of Educational Research, 74, 165-186. https://doi.org/https://doi.org/10.14689/ejer.2018.74.9

Palmer, D. H. (1999). Exploring the link between students' scientific and nonscientific conceptions. Science Education. https://doi.org/10.1002/(SICI)1098-237X(199911)83:6<639::AIDSCE1>3.0.CO;2-O

Permanasari, A. (2016). STEM Education: Inovasi dalam Pembelajaran Sains. Seminar Nasional Pendidikan Sains.

Peterson, K., \& Stone Andrew, B. (2019). From Theory to Practice: Building Leadership Opportunities through Virtual Reality Science Expeditions Kaitlin. International Journal of the Whole Child, 4(1), 67-74.

Prezhdarova, V., \& Pastarmadzhieva, D. (2020). Ensuring the security of youth in the online world: the potential of the digital art and steam education. Trakia Journal of Sciences, 18(3), 183188. https://doi.org/10.15547/tjs.2020.03.001

Radu, I. (2014). Augmented reality in education: A meta-review and cross-media analysis. Personal 
and Ubiquitous Computing, 18(6), 1533-1543. https://doi.org/10.1007/s00779-013-0747-y

Rajendra, M. I., \& Sudana, M. I. (2018). The influence of interactive multimedia technology to enhance achievement students on practice skills in mechanical technology. In Journal of Physics: Conference Series, 953. https://doi.org/IOP Publishing. https://doi.org/10.1088/1742-6596/953/1/012104

Rehmat, A. P., \& Bailey, J. M. (2014). Technology Integration in a Science Classroom: Preservice Teachers' Perceptions. Journal of Science Education and Technology. https://doi.org/10.1007/s10956-014-9507-7

Risdianto, E., \& Fathurrochman, I. (2021). Blended Learning Model Based on Massive Open Online Courses ( MOOCs ) Assisted by Augmented Reality ( BMA ) Model as the Electronic Learning Media in the Pandemic Covid-19. 13(1). https://doi.org/10.35445/alishlah.v13i1.470

Saputra, H. N., Salim, S., Idhayani, N., \& Prasetiyo, T. K. (2020). Augmented Reality-Based Learning Media Development. AL-ISHLAH: Jurnal Pendidikan. https://doi.org/10.35445/alishlah.v12i2.258

Sin, A. K., \& Zaman, H. B. (2010). Live Solar System (LSS): Evaluation of an Augmented Reality book-based educational tool. Proceedings 2010 International Symposium on Information Technology - Visual Informatics, ITSim'10. https://doi.org/10.1109/ITSIM.2010.5561320

Sirakaya, M. (2018). The Effect of Augmented Reality Use on Achievement , Misconception and Course Engagement *. 9(3), 297-314.

Slovacek, S., Miu, V., Soto, K., \& Ye, H. (2019). Supporting stem in higher education. International Journal of Education and Practice. https://doi.org/10.18488/journal.61.2019.74.438.449

Tekedere, H., \& Göker, H. (2016). Examining the Effectiveness of Augmented Reality Applications in Education: A Meta-Analysis. International Journal of Environmental and Science Education, 11(16), 9469-9481.

Thomas, R., Linder, K. E., Harper, N., Blyth, W., \& Lee, V. (2019). Current and Future Uses of Augmented Reality in Higher Education. Idea.

Tomi, A. Bin, \& Rambli, D. R. A. (2013). An interactive mobile augmented reality magical playbook: Learning number with the thirsty crow. Procedia Computer Science. https://doi.org/10.1016/j.procs.2013.11.015

Vilkoniene, M. (2009). Influence of Augmented Reality Technology upon Pupils' Knowledge about Human Digestive System: The Results of the Experiment. Online Submission.

Wang, X. Y. (n.d.). Augmented Reality: A new way of augmented learning. ELearn Magazine.

Wei, X., Weng, D., Liu, Y., \& Wang, Y. (2015). Teaching based on augmented reality for a technical creative design course. Computers and Education. https://doi.org/10.1016/j.compedu.2014.10.017

Wittayakhom, N., \& Piriyasurawong, P. (2020). Learning Management STEAM Model on Massive Open Online Courses Using Augmented Reality to Enhance Creativity and Innovation. Higher Education Studies. https://doi.org/10.5539/hes.v1on4p44

Wu, H. K., Lee, S. W. Y., Chang, H. Y., \& Liang, J. C. (2013). Current status, opportunities and challenges of augmented reality in education. Computers and Education. https://doi.org/10.1016/j.compedu.2012.10.024

Wu, P. H., Hwang, G. J., Yang, M. L., \& Chen, C. H. (2018). Impacts of integrating the repertory grid into an augmented reality-based learning design on students' learning achievements, cognitive load and degree of satisfaction. Interactive Learning Environments. https://doi.org/10.1080/10494820.2017.1294608

Yakman, G., \& Lee, H. (2012). Exploring the Exemplary STEAM Education in the U.S. as a Practical Educational Framework for Korea. Journal of The Korean Association For Science Education. https://doi.org/10.14697/jkase.2012.32.6.1072

Yen, J.-C., Tsai, C.-H., \& Wu, M. (2013). Augmented Reality in the Higher Education: Students' Science Concept Learning and Academic Achievement in Astronomy. Procedia - Social and Behavioral Sciences, 103, 165-173. https://doi.org/10.1016/j.sbspro.2013.10.322

Zhang, J., Sung, Y. T., Hou, H. T., \& Chang, K. E. (2014). The development and evaluation of an augmented reality-based armillary sphere for astronomical observation instruction. Computers and Education. https://doi.org/10.1016/j.compedu.2014.01.003 